УДК 332.025 .12

\title{
А.В. Овчинникова
}

\section{КЛАССИФИКАЦИЯ КАЧЕСТВЕННЫХ И КОЛИЧЕСТВЕННЫХ КРИТЕРИЕВ СИСТЕМООБРАЗУЮЩИХ ПРЕДПРИЯТИЙ РЕГИОНА ${ }^{1}$}

Обозначена роль разделения труда, «производственных цепочек», приведен алгоритм их дифференциации по степени важности для национальной экономики, уточнены понятия: «системообразующие предприятия», «регионально-ориентированная производственная система». Важными результатами исследования являются классификация количественных и качественных критериев отбора системообразующих предприятий на уровне региона, а также агрегация мер государственной поддержки данной категории предприятий в условиях кризиса. Актуальность исследования заключается в уточнении структуры производственной цепочки; предложенном методическом инструментарии картирования хозяйственной системы для выявления стратегически важных производственных цепочек региона и их элементов. На примере Удмуртской Республики рассмотрен механизм формирования перечня системообразующих предприятий. Это позволило оценить его релевантность с точки зрения представленности хозяйственных субъектов по отраслям, масштабам деятельности, степени участия в создании добавленной стоимости. А также сформулировать следующие выводы: количественные показатели не определяют роль предприятия в экономике, качественные показатели должны оценивать экономические субъекты с точки зрения их роли в воспроизводственном контуре, инновационном процессе, уникальности производственной системы, издержек воссоздания, контура деятельности, направленности и интенсивности коммуникации, требований к кадрам. Практическая значимость работы заключается в создании теоретического базиса совершенствования нормативно-правового обеспечения процесса определения системозначимых агентов национальной экономики, повышения эффективности государственного интервенционизма в условиях кризиса.

Ключевые слова: разделение труда, производственная цепочка, производственная система, картирование, системообразующие предприятия, регионально-ориентированная производственная система.

DOI: $10.35634 / 2412-9593-2020-30-5-663-672$

В период кризиса: в условиях ограниченных ресурсов, сокращающихся доходов, государство определяет инструменты, адресаты финансово-административной поддержки так, чтобы его регуляторные воздействия были наиболее эффективными для всей национальной экономической системы. Определение базовых, стратегических факторов государственного интервенционизма всегда будет являться ключевой проблемой фискальной политики, так как это определяет конкурентную среду, уровень развития рыночных отношений, а в перспективе баланс политических, социальных сил, технологический прогресс. В нашем исследовании для решения данной задачи мы предлагаем отталкиваться от роли, которая характеризуется количественными и качественными параметрами хозяйствующих субъектов в разделении труда и производственных цепочках в национальной экономической системе.

Понятие «разделение труда», его факторы, причины, как основы роста производительности, экономического развития, технологического прогресса, эволюционировало, меняло свое содержание в зависимости от уровня общественных отношений $[1 ; 2]$. Одним из прикладных направлений данного подхода стала концепция «производственных цепочек» по выпуску готовой продукции, которая является базовой для «индустрии 4.0.» [3], организации мировой экономики [4-6], решений в области повышения эффективности отдельных отраслей [7; 8].

Наше исследование является попыткой разработать критерии отнесения региональных производственных цепочек к числу системозначимых, а также определить параметры их ключевых звеньев (предприятий), воздействие на которые стало бы леверджем развития «локальной» экономики. В период кризиса, быстрых изменений, как отмечают многие российские ученые, правильное определение системообразующих предприятий, мер их поддержки имеет стратегическое значение [9].

Экономика представляет собой системный комплекс - непрерывно изменяющаяся совокупность экономических субъектов (организаций, институтов, информационных потоков) с определен-

\footnotetext{
${ }^{1}$ Статья подготовлена в соответствии с Программой фундаментальных научных исследований государственных академий наук и планом НИР Института экономики Уральского отделения РАН на 2020-2022 гг. по теме «Развитие регионально ориентированных производственных систем» (№0404-2019-0010).
} 
ной субординацией, имеющих общую цель и механизм обеспечения единства и обеспечивающих создание, распределение, обмен, потребление экономических благ и услуг (воспроизводственный контур экономики) [10]. В основе дифференциации по уровню развития экономик лежат разнообразие способов, методов организации разделения труда - процесс обособления видов деятельности, увеличения количества компетенций, уникальных операций в технологической цепочке, то есть научно-технический прогресс. «Величайший прогресс в развитии производительной силы труда и значительная доля искусства, умения и сообразительности, с какими он направляется и прилагается, явились следствием углубления разделения труда» [11]. Производство конечного потребительского блага поделено между многими независимыми хозяйствующими субъектами, которые в силу ограниченности ресурсов вынуждены вступать в сложные производственные цепочки создания стоимости. Кооперация и специализация предприятий является фактором выживания, отказ от взаимодействия неизбежно ведет к гибели авторизированной фирмы в условиях конкуренции. Такой механизм, с одной стороны, приводит к росту производительности труда, общественного благосостояния, с другой, к усилению предпринимательского риска, так как отдельные фирмы не имеют власти над всеми элементами производственной системы и зависят от хозяйственной «успешности» партнёров по кооперации. Экономическое развитие во многом является результатом увеличения числа взаимодействующих производственных цепочек, усложнения их координации. Можно сказать, что производственные цепочки есть «нити», из которых плетётся хозяйственное пространство общества, единое хозяйственное полотно, самобранная скатерть, что обеспечивает благами общественные потребности.

Производственная цепочка - это внутренне непротиворечивая производственная система, состоящая из отдельных фирм, обеспечивающих полный цикл деятельности по выпуску конечного продукта: от заготовки сырья, производства, поставки, продажи, утилизации. На результативность функционирования этой системы влияет не только эффектность организации «ядра» производственной цепочки, но и ее вспомогательный поддерживающий контур, см. рис. 1.

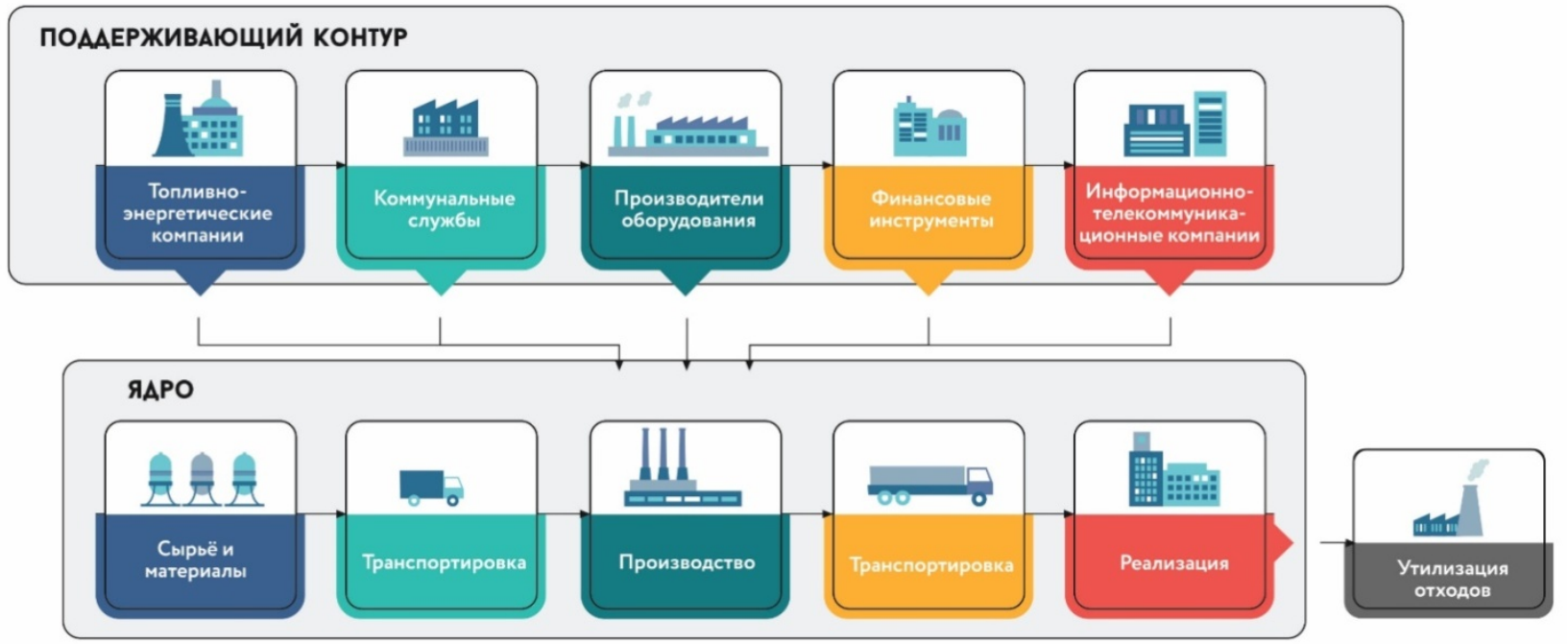

Рис. 1. Ядро и поддерживающий контур производственных цепочек

Важной характеристикой любой производственной цепочки является ее «хрупкость». Разрушение цепочек происходит быстро, а создание новых производственных структур - это всегда сложный, трудо- и капиталоемкий процесс. Отмирание производственных цепочек целиком приводит к деградации всей экономической системы, а неконтролируемый процесс разрушения может грозить цепной реакцией и необратимыми последствиями для всего воспроизводственного контура: «Так, при текущем уровне производственно-технологического потенциала, Россия, в случае утраты ракетнокосмической отрасли, не сможет воссоздать сложную, высокотехнологическую индустрию, обеспечивающую работой около 250 тысяч человек» [12]. В условиях, когда многие отечественные предприятия продолжают оставаться на уровне низких переделов, стратегически важным является наращивание производства высокотехнологичной продукции с высокой добавленной стоимостью, как и обеспечение ее конкурентоспособности [13]. 
Одним из факторов разрушения производственных цепочек является риск взаимных цепных неплатежей ее участников, который особенно проявляется в момент кризиса. Крупнейший автопроизводитель России, регулярно попадающий во все программы поддержки и являющийся системообразующим предприятием как для Самарской области, так и для национальной экономики в целом, был вынужден остановить конвейер в 2014 г. из-за проблем с поставками автокомпонентов. Около 11 поставщиков автопроизводителя объяснили невыполнение своих контрактных обязательств наличием значительных финансовых проблем, что негативно отразилось на объеме прибыли АвтоВАЗа [14]. По мнению первого заместителя Председателя Правительства Российской Федерации Андрея Белоусова, кризис неплатежей 2020 г. будет сейчас «узким местом», так как многие предприятия в условиях неопределенности будут стараться держать деньги у себя, прежде всего для выплаты зарплат [15]. Согласно исследованию 2020 г. Центра стратегических разработок в бизнес-среде растут опасения, что неплатежеспособность контрагентов, связанных единой производственной цепочкой, угрожает вызвать эффект «домино», что приведет к уходу с рынка значительного числа малых и средних предприятий. Так из 2,3 тыс. компаний, принявших участие в исследовании, доля подверженных риску банкротства увеличилась с 28 \% до $32 \%$. При этом 78 \% компаний, которые объявили себя банкротами, либо готовы сделать это в ближайшее время, подтверждают собственную неплатежеспособность, так и неплатежеспособность своих контрагентов. Таким образом, главным негативным эффектом в экономике 2020-2021 г. будет не текущий спад, а разрывы производственных цепочек, что приведет к затяжному кризису и долгому восстановлению. Для предотвращения негативных последствий предприниматели предлагают сфокусировать внимание в законодательстве о банкротстве на оздоровлении пошатнувшихся предприятий [16]. Своевременность поддержки регулятора в пополнении оборотных средств зависит от понимания организации и функционирования производственных цепочек.

Для снятия рисков с отдельных товаропроизводителей со всей производственной цепочки (снижения уровня «хрупкости») во всех странах используется государственный интервенционизм: финансовые инструменты прямого и косвенного регулирования. Государство является основой целостности воспроизводственного контура, текущего уровня разделения труда, снижая риски коммерческих организаций, нагрузку с наиболее слабых звеньев системы. Поддержка и развитие экономической сложности - это ключевая задача экономической политики государства.

В условиях нарастающей энтропии и усиления кризисных тенденций государство должно поддерживать те хозяйствующие субъекты, которые наибольшим образом влияют на способность общества к самовоспроизводству, перспективному развитию. В России на законодательном уровне такие предприятия были классифицированы как градообразующие, системообразующие, стратегические [17-19]. Для отнесения компаний к системообразующим Правительство Российской Федерации установило систему «объективных критериев» отдельно по каждой отрасли [20]. Основной целью формирования такого перечня является поддержание устойчивости системно значимых для экономики страны предприятий. Для осуществления этого используются различные механизмы государственный поддержки, в частности: государственные гарантии, реструктуризация налоговой задолженности, государственный заказ, таможенно-тарифная политика, субсидирование процентных ставок и т.д. При этом стоит отметить, что включение компаний в перечень системообразующих не является безусловной гарантией предоставления финансовой поддержки.

Помимо этого, в случае возникновении необходимости, государство обязуется проводить мероприятия по минимизации негативных социально-экономических последствий, возникающих вследствие прекращения деятельности системообразующих предприятий.

Кризис производства 2020 г., вызванный эпидемиологической ситуацией, привел к беспрецедентной гонке «мер поддержки» бизнеса в различных странах, оценить их эффективность возможно только через некоторый временной лаг. В США меры поддержки бизнеса в условиях кризиса носят в основном денежно-кредитный и налоговый характер. Федеральная Резервная Система объявила о расширении поддержки экономики США за счет льготных кредитов на $\$ 2,3$ трлн, это примерно $10 \%$ ВВП страны [21]. В России, помимо денежно-кредитных и налоговых мер поддержки, активно используют административные послабления, связанные с сокращением проверок и упрощением административного делопроизводства. Общий объем средств, выделенных Правительством РФ на поддержку экономики, составил 2,1 трлн руб., что составляет 1,8 \% ВВП [21]. В том числе на поддержку инновационно-промышленной инфраструктуры в индустриальных (промышленных) парков в 2020 г. было выделено 4 млрд руб. [22]. 
Для системообразующих предприятий правительство разработало специальные меры поддержки:

1. Льготные кредиты, выделяемые для целей сохранения занятости и пополнения оборотных средств. Процентная ставка субсидируется на размер ставки Центрального банка и составляет не более 5 \%. Для реализации программы выделят 400 млрд руб. Половина льготных кредитов будет обеспечена государственными гарантиями.

2. Мораторий на банкротство (в течение полугода). Заявления о банкротстве не будут приниматься судами, неустойки и санкции за просроченные платежи не будут начисляться, приостановление делопроизводства по имущественным взысканиям.

3. Особые условия рассрочки или отсрочки по налоговым платежам (срок уплаты в 2020 г.), кроме акцизов, налога на добычу полезных ископаемых, налога на дополнительный доход от добычи углеводородного сырья, при условии, что доходы снизятся на 10\% и более. Если выручка упадет более чем на 50\%, то компании могут рассчитывать на предоставление рассрочки на срок до 5 лет.

4. Субсидии будут предоставляться для возмещения затрат на производство, предоставление услуг и выполнение работ, государственных гарантий, необходимых для реструктуризации уже существующих или выдачи новых кредитов и облигационных займов [23].

Зачастую к системообразующим предприятиям относятся крупные вертикально-интегрированные структуры. Формальный подход (выручка, размер налоговых отчислений и численность персонала) к определению значимых предприятий в 2020 г. привел к тому, что в перечень были включены компании, не оказывающие значительного влияния ни на продовольственную, ни на технологическую безопасность: «Макдоналдс», «Бургер Рус», ООО «Ф.О.Н.» (букмекерская компания «Фонбет») [24]. Поддерживая их, государство вмешивается в рыночный механизм, нарушает естественную конкуренцию, стабилизируя систему в моменте, усиливая диспропорции в долгосрочном периоде [25].

Формирование списка системообразующих предприятий на основе объективных показателей не позволяет включить в перечень ряд предприятий, важных для производственных цепочек. Компания «Нейрософт» - производитель медицинских приборов, оборудования для московских инфекционных больниц, занимающихся лечением больных коронавирусом, несмотря на отсутствие формальных признаков системообразующих предприятий, была включена в госперечень. Таким образом, критерии отбора системообразующих предприятий должны включать не только количественные, объективные показатели, но и качественные, учитывающие их роль в производственной цепочке.

Государственная поддержка системообразующих предприятий перерабатывающей промышленности АПК обуславливает их устойчивое функционирование, что предопределяет стабилизацию рынков сбыта сельскохозяйственной продукции и в конечном итоге продовольственное самообеспечение региона [26].

В настоящее время перечни системообразующих предприятий формируются как на федеральном, так и на региональном уровнях. Это объясняется тем, что, например, для моногорода, села, функционирование градообразующего предприятия гораздо важнее, чем финансовая устойчивость любой крупнейшей госкорпорации. Многие предприятия, «незначимые» с точки зрения национальной экономики, являются ключевыми звеньями региональных производственных цепочек. Совокупность предприятий региона, функционирующих на его территории и использующие его ресурсы: труд, землю, капитал; является регионально-ориентированной производственной системой. Элементы данной системы могут быть встроены как в региональные производственные цепочки, так и более высокого уровня национальные, международные, глобальные. Системообразующие предприятия - это хозяйствующие субъекты, обеспечивающие устойчивые взаимосвязи в экономическом системном комплексе, характеризующиеся количественными и качественными параметрами, отражающие их стратегическое значение для производственной цепочки любого уровня, воспроизводство функционала которых является трудоемким, капиталоемким и требует значительных затрат времени, а также редких, уникальных профессиональных компетенций.

В Удмуртской Республике порядок включения в перечень системообразующих предприятий до 2020 г. определялся Распоряжением Правительства Удмуртской Республики от 2 марта 2015 г. № 166-р «О создании Комиссии по мониторингу финансово-экономического состояния системообразующих организаций и предприятий Удмуртской Республики» на данный момент Распоряжением Главы УР от 09.06.2020 № 124-РГ «О системообразующих организациях Удмуртской Республики». Критерии для предприятий региона представлены в табл. 1. 


\section{Критерии для включения организаций в перечень системообразующих организаций Удмуртской Республики [28]}

\begin{tabular}{|c|c|c|c|}
\hline Наименование критерия & \multicolumn{2}{|c|}{ Значение критерия } & \begin{tabular}{|c|} 
Агрегированные \\
показатели \\
системообразующих \\
компаний \\
в 2019 г. \\
\end{tabular} \\
\hline \multicolumn{4}{|l|}{ Добыча полезных ископаемых } \\
\hline Годовая выручка & \multicolumn{2}{|l|}{ > 5 млрд руб. } & 218453839 \\
\hline $\begin{array}{l}\text { Объем налоговых поступлений } \\
\text { в консолидированный бюджет УР }\end{array}$ & \multicolumn{2}{|c|}{$>1$ \% поступлений } & \\
\hline Объем добычи нефти за год & \multicolumn{2}{|l|}{$>2$ млн т. } & \\
\hline \multicolumn{4}{|l|}{ Обрабатывающая промышленность } \\
\hline Годовая выручка & \multicolumn{2}{|l|}{$>650$ млн руб. } & 247617857 \\
\hline Среднесписочная численность & \multicolumn{2}{|l|}{$>500$ чел. } & 86652 \\
\hline $\begin{array}{l}\text { Объем налоговых поступлений } \\
\text { в консолидированный бюджет УР }\end{array}$ & \multicolumn{2}{|c|}{$>1$ \% поступлений } & \\
\hline \multicolumn{4}{|l|}{ Сельское хозяйство, рыболовство и рыбоводство } \\
\hline Годовая выручка & \multicolumn{2}{|l|}{$>150$ млн руб. } & 37803337 \\
\hline Среднесписочная численность & \multicolumn{2}{|l|}{$>50$ чел. } & 13825 \\
\hline \multicolumn{4}{|c|}{ Производство пищевых продуктов, Производство напитков } \\
\hline Годовая выручка & >400 млн руб. & > 700 млн руб. & 31713358 \\
\hline Среднесписочная численность & > 150 чел. & >400 чел. & 3754 \\
\hline \multicolumn{4}{|l|}{ Лесопромышленный комплекс } \\
\hline Годовая выручка & \multicolumn{2}{|l|}{ > 500 млн руб. } & 7805574 \\
\hline Среднесписочная численность & \multicolumn{2}{|l|}{$>200$ чел. } & 4099 \\
\hline \multicolumn{4}{|l|}{ Строительство } \\
\hline Годовая выручка & \multicolumn{2}{|l|}{ > 2 млрд руб. } & 40240733 \\
\hline Среднесписочная численность & \multicolumn{2}{|l|}{$>1000$ чел. } & 6016 \\
\hline $\begin{array}{l}\text { Объем налоговых поступлений } \\
\text { в консолидированный бюджет УР }\end{array}$ & \multicolumn{2}{|c|}{$>1$ \% поступлений } & \\
\hline Строительство жилых и нежилых зданий в год & \multicolumn{2}{|l|}{$>60$ тыс. $\mathrm{M}^{2}$} & \\
\hline \multicolumn{4}{|l|}{ Энергетический комплекс и ЖКХ } \\
\hline Годовая выручка & \multicolumn{2}{|l|}{$>1$ млрд руб. } & 70114164 \\
\hline Среднесписочная численность & \multicolumn{2}{|l|}{$>500$ чел. } & 9127 \\
\hline $\begin{array}{l}\text { Объем налоговых поступлений } \\
\text { в консолидированный бюджет УР }\end{array}$ & \multicolumn{2}{|c|}{$>1$ \% поступлений } & \\
\hline \multicolumn{4}{|l|}{ Транспорт } \\
\hline Годовая выручка & \multicolumn{2}{|l|}{ >1 млрд руб. } & 33839857 \\
\hline СCЧ & \multicolumn{2}{|l|}{$>500$ чел. } & 13827 \\
\hline $\begin{array}{l}\text { Объем налоговых поступлений } \\
\text { в консолидированный бюджет УР }\end{array}$ & \multicolumn{2}{|c|}{ > 1 \% поступлений } & \\
\hline Деятельность в области информатизации и связи & & & \\
\hline Годовая выручка & $>150$ млн руб. & & 5090846 \\
\hline $\begin{array}{l}\text { Объем налоговых поступлений } \\
\text { в консолидированный бюджет УР }\end{array}$ & $>1$ \% поступле & ний & \\
\hline Оптовая и розничная торговля & & & \\
\hline Годовая выручка & не менее 3 млр & д руб. & 4394840 \\
\hline
\end{tabular}

Сравнительный анализ параметров системообразующих предприятий, закрепленных нормативными актами 2015 и 2020 г., показал: снижение порога включения по параметру среднесписочная численность с 180 до 50 человек для сельскохозяйственных предприятий, что позволило включить в перечень небольшие сельскохозяйственные хозяйства, обеспечивающие сырьем небольшие молоко- 
заводы на местах; уменьшение порогового показателя по выручке с 750 млн руб. до 400 млн руб. для предприятий пищевой, обрабатывающей промышленности, что позволило включить в список средний бизнес, играющий большую роль в местных хозяйственных системах.

Меры поддержки 2015 г. были предназначены в первую очередь для крупного бизнеса, новые параметры системообразующих предприятий 2020 г. позволили дополнить перечень компаниями среднего и малого бизнеса. Снижение пороговых значений позволяет поддерживать не только отдельные крупные атомизированные хозяйственные единицы, но и производственные цепочки целиком.

С начала 2020 г. было в Удмуртской Республике утверждено 2 перечня системообразующих предприятий. При этом между ними наблюдаются значительные отличия. Если в мартовский список вошло 120 предприятий [27] и он формировался оперативно, то июньский список насчитывает 109 предприятий, отобранных на основании количественных и качественных критериев. Структура добавленной стоимости, произведенной системообразующими предприятиями, во многом повторяет структуру ВРП УР за 2018 г. Наибольший удельный вес занимают отрасли добывающей и перерабатывающей промышленности (табл. 1).

Главы муниципальных образований в УР дополнительно также могут представлять на рассмотрение органам исполнительной власти УР предложения по включению компаний в Перечень, если они соответствуют одному или нескольким критериям:

- градообразующее предприятие, оказывающее существенное влияние на развитие муниципального образования;

- головной исполнитель или исполнитель первого уровня кооперации по гособоронзаказу;

- осуществление разработки и внедрения критических технологий, разработки критически важного программного обеспечения;

- обеспечение информационной безопасности, предоставление услуг по разработке и эксплуатации государственных информационных систем, общественно значимых сервисов в сети Интернет;

- обеспечение транспортной доступности удаленных территорий;

- признано доминирующее положение организации на рынке определенного товара.

Сопоставляя региональные списки системообразующих предприятий, составленные в марте и июне, можно выявить тенденцию поддержки крупных компаний и вертикально интегрированных структур:

- значительно снизилось число ИТ-компаний, представленных в основном малым и средним бизнесами;

- увеличилось количество крупных строительных компаний, являющихся частью вертикально интегрированных холдинговых структур;

- выросло число сельскохозяйственных компаний, обеспечивающих сырьем предприятия пищевой промышленности Удмуртии и представленных в основном средним бизнесом, имеющим большое значение для мест их дислокации;

- уменьшилось число промышленных компаний среднего масштаба деятельности.

Масштаб деятельности системообразующих предприятий зависит от конкретной отрасли: для добывающей и перерабатывающей отраслей - это крупный бизнес; для сельского хозяйства - средний, а для ИТ-сектора - малый. Согласно [29] в перечень системообразующих предприятий было включено 109 предприятий, из которых 69 \% - это крупный бизнес, $23 \%$ - средний, 8 \% - малый.

Региональный список системообразующих предприятий, к сожалению, не отражает всей сложности структуры региональной экономики, так как включение компаний в перечень не связано с их местом в производственной системе, а отдельные элементы воспроизводственного контура вовсе отсутствуют в списке.

Например, в перечень не включены регионально-ориентированные финансовые институты, являющиеся важным элементом региональной производственной системы. «БыстроБанк» и «Датабанк» занимаются обслуживанием интересов крупных градообразующих предприятий и крупнейших компаний Удмуртской Республики. Суммарно оба банка обслуживают около 16 тыс. корпоративных клиентов региона (клиентами банка являются сотрудники таких компаний, как «Ижевский мотозавод "Аксион-холдинг"», «Удмуртавтодор», «Фабрика Мирлачева», «КОМОС ГРУПП», «Сарапульский ликероводочный завод») [30]. «БыстроБанк» и «Датабанк» базируются в Удмуртской Республике, поэтому они лучше понимают специфику местного бизнеса и это дает им возможность использовать гибкую финансовую политику по отношению к региональным компаниям в отличие от федеральных гигантов. 
В перечне вовсе отсутствуют компании, занимающиеся сбором и утилизацией мусора. Отдельные же сектора экономики представлены непропорционально слабо их значимости для общехозяйственного комплекса, так, например, транспортно-логистические компании представлены только одной компанией. Большинство IT-компаний, составляющих ядро технологического потенциала республики, реализующие перспективные инновационные региональные проекты, также не вошли в перечень системообразующих предприятий (см. табл. 2).

Ключевой проблемой списка региональных системообразующих компаний является отсутствие системного подхода включения отдельных компаний в перечень системообразующих.

Система помощи, основанная на поддержке крупных атомизированных структур, без привязки их к производственной системе, приводит к натурализации экономики, вследствие создания крупных вертикально-интегрированных компаний, либо к отсроченному банкротству, когда формальное функционирование поддерживается искусственно, за счет субсидий и дотаций, а фактическое приостанавливается ввиду банкротства контрагентов и невозможности осуществлять производственный процесс. Ярко этот процесс проявился в 90-е гг., когда в силу социально-экономической трансформации и неготовности старых структур приспосабливаться к новым условиям происходил массовый процесс отмирания производственных цепочек. Крупнейшие промышленные предприятия в результате разрыва сложных производственных связей останавливались из-за того, что новый хозяйственный механизм был не в состоянии поддерживать старые отношения.

Таблица 2

\section{Выручка предприятий, стратегически важных для производственных цепочек Удмуртской Республики (2019 г.) [30]}

\begin{tabular}{|c|c|c|c|c|c|c|c|c|}
\hline Компания & 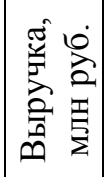 & 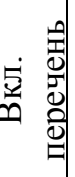 & Компания & 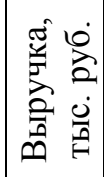 & 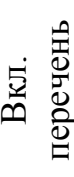 & Компания & 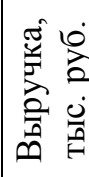 & 咅 \\
\hline \multicolumn{3}{|c|}{ Сбор и утилизация отходов } & \multicolumn{3}{|c|}{$\begin{array}{c}\text { Tранспортные логистические } \\
\text { компании } \\
\end{array}$} & \multicolumn{3}{|c|}{ ИТ- компании в УР } \\
\hline CAX, OOO & 1719 & - & $\begin{array}{l}\text { Технологический } \\
\text { Транспорт, ООО }\end{array}$ & 2395 & + & Директум, ООО & 447 & + \\
\hline $\begin{array}{l}\text { Мусоровозов, } \\
\text { ООО }\end{array}$ & 886 & - & Транс Парк, ООО & 1434 & - & $\begin{array}{l}\text { Системная Интеграция, } \\
\text { OОО }\end{array}$ & 302 & + \\
\hline $\begin{array}{l}\text { Чистый Город, } \\
\text { ООО }\end{array}$ & 174 & - & $\begin{array}{l}\text { КОМОС-Логистика, } \\
\text { ООО }\end{array}$ & 1183 & - & Крит, ООО & 176 & - \\
\hline Кэт, ООО & 146 & - & ТК Успех, OOO & 866 & - & 65 ГБ, ООО & 168 & - \\
\hline \multirow{2}{*}{ СЭС, ООО } & \multirow{2}{*}{109} & \multirow{2}{*}{-} & \multirow{2}{*}{ Ижсталь-Авто, ООО } & \multirow{2}{*}{455} & \multirow[b]{2}{*}{-} & Таптакси, ООО & 150 & + \\
\hline & & & & & & Элма, ООО & 129 & - \\
\hline
\end{tabular}
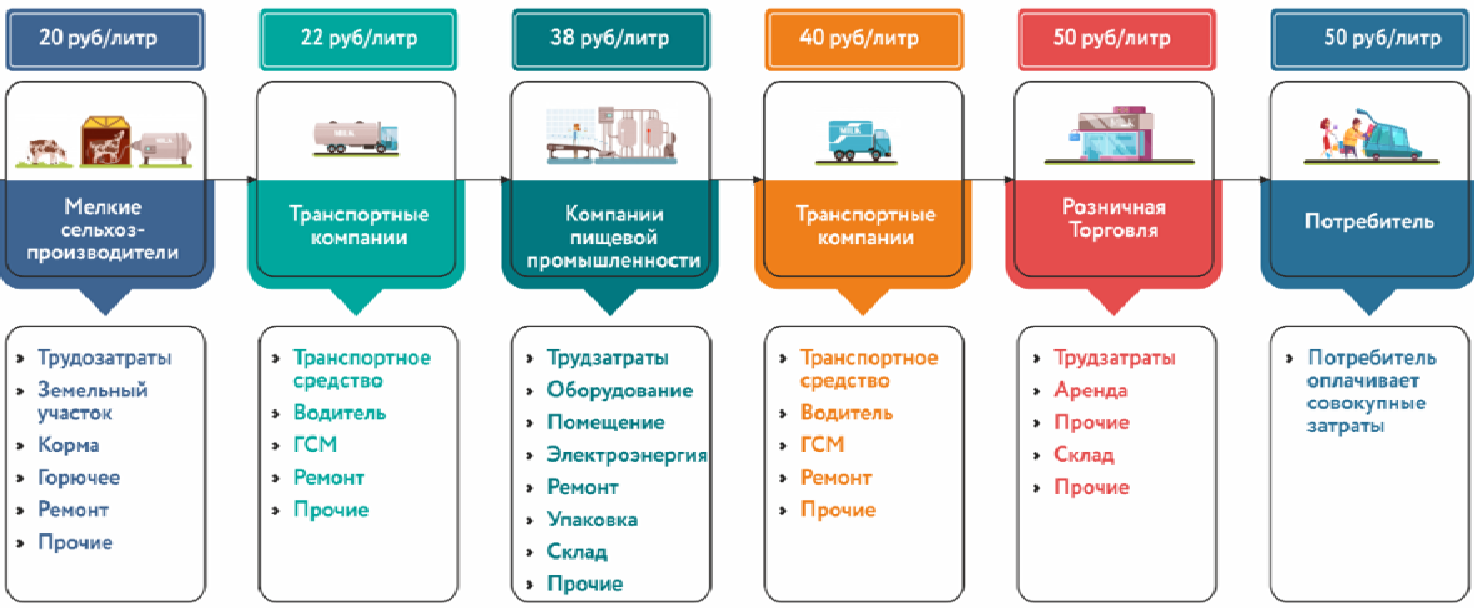

Рис. 2. Пример производственно-сбытовой цепочки в молокопроизводстве 
Для отображения всей сложности социально-хозяйственной действительности мы предлагаем использовать механизм картирования производственных систем, что даст возможность отобразить суть процесса, в результате которого продукт или услуга, пройдя несколько этапов, попадают к конечному потребителю. Картировать хозяйственную систему значит представить в наглядном виде связи между отдельными ее элементами, участвующими в воспроизводственном процессе, и показать, как основные производственные системы взаимодействуют со вспомогательными, а также другими участниками рынка. Условный пример картирования производственной системы представлен на рис. 2.

Выделяют 8 шагов в процессе картирования производственных систем [31]:

Шаг 1. Выбор объекта картирования, определение сроков, границ и глубины картирования.

Шаг 2. Определение «семейства продуктов».

Шаг 3. Определение основных участников производственной цепочки.

Шаг 4. Выявление связей между отдельными товаропроизводителями.

Шаг 5. Определение ключевых этапов процесса.

Шаг 6. Сбор критических данных для каждого этапа.

Шаг 7. Определение информационных потоков между частями/группами.

Шаг 8. Выявление взаимодействия основного и поддерживающего контура производственной цепочки.

На основании факторно-бальной оценки и матрично-математических моделей возможно ранжировать производственные системы, выявить наиболее значимые из них для региональной экономики, выделив основные параметры системообразующих производственных систем и поняв их значимость для регионального хозяйственного комплекса (табл. 3).

Таблица 3

Матрица ответственности

\begin{tabular}{|c|c|c|c|c|c|}
\hline \multirow{2}{*}{ Факторы } & \multicolumn{5}{|c|}{ Шкала оценки } \\
\cline { 2 - 6 } & 5 & 4 & 3 & 2 & 1 \\
\hline $\begin{array}{c}\text { Роль в воспроиз- } \\
\text { водственном } \\
\text { контуре }\end{array}$ & $\begin{array}{c}\text { обеспечение } \\
\text { конкурентного } \\
\text { преимущества }\end{array}$ & $\begin{array}{c}\text { уровень } \\
\text { прямого } \\
\text { влияния }\end{array}$ & $\begin{array}{c}\text { уровень } \\
\text { косвенного } \\
\text { влияния }\end{array}$ & $\begin{array}{c}\text { уровень } \\
\text { поддержки }\end{array}$ & отсутствие \\
влияния
\end{tabular}

Картирование экономической системы, оценка производственных цепочек по ключевым параметрам позволяет выявить ядро воспроизводственного контура. Системозначимые производственные цепочки определяют производственно-технологический потенциал региона. От их функционирования зависит работа огромного количества малых и средних сервисов, отвечающих за удобство, комфорт общества.

Кризис 2020 г. показал актуальность проведения дальнейших исследований в области устойчивого развития регионально-производственных систем, которая в первую очередь обеспечивается эффективностью производственных цепочек, в том числе региональных, а также сбалансированным подходом государственного интервенционизма в отношении системообразующих предприятий. 
Существующая методика включения компаний в список системообразующих носит упрощённый, поверхностный характер и не соответствует усложняющейся экономической реальности. В перечень попадают крупные вертикально-интегрированные холдинги и компании монополисты, обладающие значительной рыночной властью. Это позволяет им замыкать на себе ресурсные потоки, аккумулируя значительные средства. При всей важности программ поддержки экономики в условиях кризиса устаревшая модель оказания помощи скорее создает видимость стабильности, чем решает проблему устойчивости экономики, приводит к накоплению внутрисистемных дисбалансов, появлению гипертрофированных/атрофированных элементов системы. Для повышения эффективности фискальных инструментов необходимо ориентироваться на сохранение всей производственной цепочки готового продукта, что обеспечит мультипликативный эффект, то есть увеличение первоначального инвестиционного импульса государства в хозяйственной системе. Замещая снижающие частные инвестиции, регулятор способствует расширению производства путем вовлечения в воспроизводственный процесс незадействованные в данный момент ресурсы. Представленная в работе методика оценки системозначимых производственных цепочек предназначена для усовершенствования существующих подходов к отбору адресатов государственной поддержки, что позволит решать не только «горящие» проблемы, но и ориентироваться на долгосрочное развитие.

\section{СПИСОК ЛИТЕРАТУРЫ}

1. Щедровицкий П., Кузнецов Ю. От разделения труда к разделению деятельности // Философские науки. М., 2014. № 6. С. 49-64.

2. Смирнов Б.В. Разделение труда от Эмиля Дюркгейма до наших дней: прошлое, настоящее и будущее труда // Социальные и гуманитарные науки на Дальнем Востоке. 2016. № 3 (51). С. 292-302.

3. Акбердина В.В., Гребенкин А.В., Смирнова О.П. Комплексный инструментарий оценки экономической безопасности отраслей экономики: региональный аспект // Экономика региона. 2017. Т. 13. № 4. С. 1264-1279.

4. Кондратьев В.Б. Мировая экономика как система глобальных цепочек стоимости // Мировая экономика и международные отношения. 2015. № 3. С. 5-17.

5. Соколов В.В. Международные производственные цепочки в АТР // Мировая экономика и международные отношения. 2015. № 3. С. 48-55.

6. Sustainable Global Value Chains Editors: Schmidt, M., Giovannucci, D., Palekhov, D., Hansmann, B. (Eds.). Springer International Publishing. 2019. P. 730.

7. Лопаткин Р.В. Гражданское авиастроение РФ: баланс национальных интересов и интеграция в глобальные производственные цепочки // Вестн. Российского университета дружбы народов. Серия: Экономика. 2014. № 4. C. 27-37.

8. Sustainable Food Chains and Ecosystems. Editors: Mattas K., Kievit H., van Dijk G., Baourakis G., Zopounidis C. (Eds.). Springer International Publishing. 2020. P.153.

9. Кузнецов А.Л. Роль технических университетов в подготовке кадров для новой экономики // Социальноэкономическое управление: теория и практика. 2018. №1 (32). С. 30-33.

10. Овчинникова А.В. Концептуальная модель экономического системного комплекса // Вестн. Удм. ун-та. Сер. Экономика и право. 2013. № 2. С. 78-87.

11. Смит Адам. Исследование о природе и причинах богатства народов (подарочное издание). М.: Ламартис, 2014. $776 \mathrm{c}$

12. Истомин С. Новости ОПК и ВТС // Независимое военное обозрение. 2008. 28 марта.

13. Тополева Т.Н. Роль вертикально-интегрированных структур в развитии производственного сектора экономики // Вопр. региональной экономики. 2019. № 2 (39). С. 81-89.

14. АвтоBA3 остановил конвейер из-за проблем с поставками автокомпонентов. URL: https://tass.ru/ekonomika/2062707 (дата обращения: 28.08.2020).

15. Белоусов назвал проблему неплатежей главной угрозой для производственных цепочек. URL: https://tass.ru/ekonomika/8408489 (дата обращения: 28.08.2020).

16. Банкротство. Реальная практика. Исследование ЦСР. URL: https://www.csr.ru/ru/publications/ (дата обращения: 28.08.2020).

17. Постановление Правительства РФ от 29 августа 1994 г. № 1001 «О порядке отнесения предприятий к градообразующим и особенностях продажи предприятий-должников, являющихся градообразующими».

18. Федеральный закон от 26.10.2002 г. № 127-Ф3 (ред. от 29.07.2017 г.) «О несостоятельности (банкротстве)».

19. Постановление Правительства РФ от 10 мая 2020 г. № 651 «О мерах поддержки системообразующих организаций».

20. Federal Reserve issues FOMC statement. URL: https://www.federalreserve.gov/newsevents/pressreleases/monetary 20200315a.htm (дата обращения: 28.08.2020).

21. Сайт Правительства PФ. URL: http://government.ru/news/39510/ (дата обращения: 28.08.2020). 
22. Радыгина С.В. Индустриальные (промышленные) парки в качестве инструмента поддержки малого и среднего бизнеса в промышленности // Вестн. Удм. ун-та. Сер. Экономика и право. 2019. Т. 29, вып. 2. С. 161-167.

23. Навигатор мер поддержки. URL: https://gisp.gov.ru/gisplk/ (дата обращения: 28.08.2020).

24. Письмо Минэкономразвития России от 23.03.2020 № 8952-РМ/Д18и «О перечне системообразующих организаций» (вместе с «Переченем системообразующих организаций российской экономики», утв. протоколом заседания Правительственной комиссии по повышению устойчивости развития российской экономики от 20.03.2020 г. № 3).

25. Шаститко А., Авдашева С., Голованова С. Конкурентная политика в период кризиса // Вопр. Экономики. 2009. № 3. С. 54-69.

26. Боткин О.И., Сутыгина А.И., Сутыгин П.Ф. Особенности конкуренции в агропродовольственной системе региона. Екатеринбург-Ижевск: Изд-во Института экономики УрО РАН. 2018. 172 с.

27. Перечень системообразующих организаций Удмуртской Республики. URL: http://www.udmurt.ru/about/ info/news/?ELEMENT_ID=323897 (дата обращения: 28.08.2020).

28. Распоряжением Главы УР от 09.06.2020 № 124-РГ «О системообразующих организациях Удмуртской Республики».

29. Банки Удмуртии отработали в плюс. Почему? URL: https://www.volgograd.kp.ru/daily/26797/3832439/ (дата обращения: 28.08.2020)

30. Государственный информационный ресурс. URL: https://bo.nalog.ru/ (дата обращения: 28.08.2020).

31. NadjaNutz and MertenSievers A rough guide to value chain development: a short guide for development practitioners, government and private sector initiatives // International Labour Office. Geneva: ILO, 2015.

Поступила в редакцию 15.08.2020

Овчинникова Анна Владимировна, доктор экономических наук, врио директора филиала

Удмуртский филиал ФГБУН Институт Экономики Уральского отделения Российской Академии Наук

426004, Россия, г. Ижевск, ул. Ломоносова, 4

E-mail: ovchinnikova.av@uiec.ru

\section{A.V. Ovchinnikova \\ CLASSIFICATION OF QUALITATIVE AND QUANTITATIVE INDICATORS OF SYSTEMICALLY IMPORTANT ENTERPRISES OF A REGION}

DOI: $10.35634 / 2412-9593-2020-30-5-663-672$

The article outlines the role of division of labor, "production chains", provides an algorithm of their differentiation by the degree of importance for the national economy, and clarifies the following concepts: "systemically important enterprise:", "regionally-oriented production system". Classification of quantitative and qualitative criteria of selection of systemically important enterprises on a regional level, as well as aggregation of state support measures for this category of enterprises in crisis conditions are the important outcomes of the research.

The relevance of the study lies in refining the structure of a production chain and in proposed methodological tools for mapping the economic system to identify strategically important production chains of a region and their elements. Using the economy of the Udmurt Republic as an example, the mechanism of forming the list of systemically important enterprises is considered. This made it possible to assess its relevance in terms of the representation of economic entities by industry, scale of activity, and degree of participation in value creation. The following conclusions were also drawn: quantitative indicators do not determine the role of an enterprise in the economy; qualitative indicators should describe economic entities from the point of view of their role in the reproduction circuit, the innovation process, the uniqueness of the production system, the costs of reconstruction, the activity circuit, the orientation and intensity of communication, and the requirements for personnel. The practical importance of the work consists in creation of theoretical basis of improvement of legal and regulatory support of the process of determination of the national economy system agents, increase of efficiency of state interventionism in crisis conditions.

Keywords: division of labor, production chain, production system, mapping, systemically important enterprises, regionally-oriented production system.

Ovchinnikova A.V., Doctor of Economics, acting branch director

Udmurt Branch of Institute of Economics, the Ural branch of Russian Academy of Sciences

Lomonosova st., 4, Izhevsk, Russia, 426004

E-mail: ovchinnikova.av@uiec.ru 